цивилизации / А. Д. Урсул // Вестник РОИВТ. - 1993. - № 1-2. - С. 35-45. 4. Поліщук Н. В. Науково-технічний прогрес i духовно-моральне становлення молоді: [монографія] / Н. В. Поліщук - Рівне : О. Зень, 2012. - 464 с. 5. Поліщук Н. В. Філософсько-освітні перспективи пізнання Всесвіту та виховання духовних людей космічно-інопланетного майбутнього / Н. В. Поліщук // Философия и космологія / Philosophy Cosmology 2013. - Киев, 2014. - С. 190-200.

УДК 378.147 .88

Любов Продан

\title{
ПІДГОТОВКА МАЙБУТНЬОГО СУЧАСНОГО ВЧИТЕЛЯ ПОЧАТКОВИХ КЛАСІВ ЗАСОБАМИ КРАЕЗНАВЧОГО МУЗЕЮ
}

Продан Л. А. Підготовка майбутнього сучасного вчителя початкових класів засобами краєзнавчого музею.

У статті йдеться про шляхи успішної професійної підготовки вчителів початкових класів засобами краєзнавчого музею. Охарактеризовано види роботи у краєзнавчому музеї ВН3, які використовуються викладачами під час роботи зі студентами. 3'ясовано значення краєзнавчого музею у формуванні особистості вчителя. Досліджено, які завдання пробуджують у студентів інтерес до краєзнавчої роботи, розвивають у них дослідницькі навички, ініціативу та творчість.

Ключові слова: краєзнавчий музей, краєзнавча педагогіка, підготовка майбутнього вчителя, дослідницька робота.

Продан Л. А. Подготовка будущего современного учителя младших классов средствами краеведческого музея.

В статье говорится о путях успешной профессиональной подготовки учителей начальных классов средствами краеведческого музея. Охарактеризованы виды работы в краеведческом музее вузов, которые используются преподавателями во время работы со студентами. Исследовано, какие задачи пробуждают в студентах интерес к краеведческой работе, развивают в них исследовательские навыки, инициативу и творчество.

Ключевые слова: краеведческий музей, краеведческая педагогика, подготовка будущего учителя, исследовательская работа.

Prodan L. A. Training the future primary school teacher by addressing materials of local history museum.

The article discusses ways of successful professional training of primary school teachers in the context of addressing materials of local history museum. The author characterizes kinds of work to be done in universities' local history museums which students accompanied by their university teachers attend. The article clarifies what tasks motivate students' interest in local history, develop their research skills, initiative and creativity.

Key words: local history museum, history education, training of future teachers, research work.

Ефективність реалізації завдань реформування освіти, спрямованих на виховання національно свідомих і освічених громадян України, багато в чому залежить від краєзнавчої підготовки сучасного майбутнього вчителя початкової школи та його обізнаності в роботі краєзнавчого музею.

Краєзнавчий музей, як ефективний шлях створення культуротворчого 
середовища у навчально-виховному процесі педагогічного ВНЗ, відкриває студенту довкілля 3 усією багатогранністю складних взаємозв'язків природи, суспільства й особистості, задовольняє потреби в самопізнанні, самореалізації, сприяє формуванню особистісних якостей, ціннісних орієнтацій тощо.

Проблемі навчання та виховання майбутніх учителів засобами краєзнавчого музею приділено увагу у працях В. Обозного, Ю. Руденка, М. Стельмаховича, В. Струманського та ін. Роль роботи 3 краєзнавчим музеєм у професійній діяльності вчителя з учнями початкової школи розкрито в сучасних дослідженнях В. Матіяш, Т. Міщенко, О. Пірожкової.

Метою статmі є визначення ролі засобів краєзнавчого музею, що використовуються в навчальному процесі ВН3, оцінка й аналіз особливостей упровадження їх у систему підготовки майбутніх сучасних учителів початкової школи.

Адаптація майбутніх учителів початкової школи до професійної діяльності в умовах певного регіону 3 урахуванням особливостей рідного міста чи села спрямовується на вивчення і дослідження питань долучення майбутніх учителів до історико-педагогічної культури краю. Матеріали краєзнавчого музею допомагають оволодіти конкретними знаннями про специфічні особливості розвитку регіону; засвоїти краєзнавчі знання, сприяє формуванню в учнів діалектичного мислення. Краєзнавчий музей- це засіб безпосереднього чуттєво-раціонального пізнання конкретних об'єктів довкілля, ефективний засіб патріотичного, трудового, фізичного виховання, розвитку громадської активності і професійної орієнтації.

Якість підготовки майбутніх учителів до краєзнавчої роботи 3 учнями в початковій школі вимагає ретельної роботи викладачів ВНЗ. Підготовка сучасного вчителя є важливою умовою не тільки ефективного використання ним матеріалів 3 історії рідного краю в навчально-виховному процесі і залучення учнів до краєзнавчих пошуків, а й особистої його участі в науково-дослідній роботі. Будучи організатором краєзнавчого музею в навчальному закладі, учитель сам повинен володіти дослідницьким методом і методикою навчання учнів елементів дослідницької роботи. Він повинен знати: основні джерела 3 історії рідного краю, методи їх вивчення i використання в навчально-виховній роботі; основні проблеми сучасної історичної та інших соціально-гуманітарних наук; проблеми місцевої археології, етнографії, топоніміки; особливості учнівських досліджень з краєзнавчої тематики.

Основною формою організації краєзнавчої роботи в сучасних навчальних закладах є музейна педагогіка, інноваційна педагогічна технологія, яка грунтується на інтеграції суспільно-гуманітарних наук: історії, музеєзнавстві, мистецтвознавстві, природознавстві, культурознавстві, лінгвістиці, соціології, психології та сприяє розвиткові творчих здібностей учнів.

Краєзнавчий музей є важливим освітньо-виховним осередком і будує свою роботу на основі Положення про музей при закладі освіти. Вивчення минулого свого краю немислиме без опрацювання пам'яток, документів і матеріалів. Як із наукового, так і педагогічного погляду, експедиція, похід чи акція, робота краєзнавчого гуртка втрачає свою цінність, якщо не планується збір матеріалів для колекцій. Колекціонування, у свою чергу, потребує створення музею. Даючи учням навички дослідницької роботи, активізуючи творчу діяльність, шкільні музеї сприяють патріотичному вихованню підростаючого покоління.

У процесі навчання студентів робота в краєзнавчому музеї навчального закладу виконує такі функції: виховну, освітню, розвивальну, організаційну, мотиваційну, практично-орієнтовану, теоретико-методологічну. Адже саме вивчення основ 
історико-педагогічного краєзнавства сприяє вихованню таких якостей, як: громадянськість, патріотизм, любов до рідного краю; формується творчий підхід до вивчення i використання місцевого історико-педагогічного досвіду, а також індивідуальний стиль діяльності, спрямованість на професію вчителя, повага до педагогічної діяльності, розвиваються комунікативні уміння (слухати, вести діалог, бесіду, ставити питання, встановлювати особисті контакти тощо), педагогічний такт [2, с. 56-57].

Гнучке використання засобів, методів, прийомів, що сприяють активному мисленню студентів, постійному творчому пошуку, оновленню ідей, зумовлює більш глибоке й продуктивне засвоєння ролі й місця краєзнавчої роботи вчителя в організації навчально-виховного процесу, оскільки саме в краєзнавчому музеї закладено потужні потенційні можливості підготовки майбутнього вчителя до означеної сфери діяльності. Залучення студентів до активної педагогічно-краєзнавчої діяльності сприяє впровадженню активних форм і методів у навчально-виховний процес. Особливого значення набуває моделювання проблемних ситуацій, різноманітних дискусій, ділових ігор, завдань творчого та навчально-дослідного характеру, проведення засідань круглих столів, конференцій, педагогічних читань, виставок, захист науково-дослідних робіт тощо. Організація такої роботи сприяє удосконаленню знань, умінь і навичок студентів 3 краєзнавчої роботи. Необхідно зазначити, що оновлення форм і методів навчально-виховного процесу сприяють суб'єкт-суб'єктній взаємодії студентів з викладачами. 3 огляду на це завдання мають творчий, дослідницький характер, особистісну спрямованість і моделюють різні аспекти краєзнавчої діяльності.

Організоване в такий спосіб навчання у вищій педагогічній школі сприяє успішній підготовці до майбутньої педагогічно-краєзнавчої діяльності вчителів початкових класів. Такий підхід дозволяє значно вдосконалити педагогічнокраєзнавчі знання студентів, сконцентрувати й систематизувати матеріал, чим досягається активність студентів у краєзнавчій роботі [3].

Краєзнавчий музей при ВНЗ спияє розвитку особливої галузі - педагогічного краєзнавства, яке досліджує історію освіти краю, відомі персоналії, розвиток системи народної освіти і педагогічної думки в етнічних групах, а також історію народної освіти в області, районі, населеному пункті тощо. Об'єктом педагогічного краєзнавства $є$ історія педагогіки того чи іншого краю на тлі загального перебігу подій, а також соціальна (активно-перетворювальна) функція людини, яка виявляється в мистецьких творах, що стають пам'ятками педагогіки, де зібрано досвід поколінь. Саме вивчення курсу педагогічного краєзнавства стає підгрунтям для переосмислення історичних подій минулого в Україні та виховує в майбутнього вчителя національні інтереси, прагнення й почуття.

Краєзнавчі ідеї, є частиною галузі української етнопедагогіки, почали впроваджуватися в навчально-виховну практику ще в школах Київської Русі. Опанування учнями історичних, педагогічних, географічних знань пов'язувалося 3 відомостями про культурну спадщину рідного краю. Безіменні народні «краєзнавці»знавці місцевої історії- передавали 3 покоління до покоління свої знання, які зберігалися в народній пам'яті, відбивалися в давніх літописах.

Кращі представники української інтелігенції: письменники (Т. Шевченко, М. Старицький, І. Франко, Л. Українка), педагоги (К. Ушинський, П. Каптерєв, С. Русова, Х. Алчевська, Б. Грінченко), етнографи (П. Куліш, П. Чубинський, Д. Яворницький та інші) розпочали велику роботу з вивчення культурної спадщини українського народу, заклали підвалини наукового напрямку краєзнавства, 
народознавства, українознавства [1, с. 44-46].

Так, К. Ушинський одним із перших звернув увагу на необхідність розвивати в дітей «інстинкт місцевості»- здатність бачити довкілля в контексті природи, суспільства, культури, виступав за введення до навчальних планів курсу, що ознайомлював би учнів 3 історією народу, його національним характером, психологією, культурно-історичними традиціями та звичаями. Він радив Міністерству освіти скласти точну і чітку програму цього курсу, опублікувати методичну літературу до нього i відтак покласти початок запровадженню курсу «Вітчизнознавство» у школі. Педагог-гуманіст уперше визначив краєзнавство як педагогічне поняття, виокремлюючи суспільний, освітньо-виховний і педагогічний аспекти. Він рекомендував вивчати шкільні предмети (мову, географію, історію) за принципом «кола, що розширюється»: від знайомого, близького (рідний край), до загального (країна) [3, с. 31-34].

Загалом аналіз історико-педагогічної літератури з краєзнавства дозволяє зробити висновок, що специфіка краєзнавчої роботи в історії та практиці навчально-виховної роботи з учнями початкових класів $є$ багатогранною. Краєзнавство, як галузь педагогічного знання, грунтується на знанні вчителем культури та побуту свого народу, знаннях про рідний край, а також умінні донести дітям свої знання, що потребує великого таланту і мистецтва. Краєзнавство грунтується на історичному, педагогічному, психологічному та географічному аспектах, здобутках педагогічної науки та методичному досвіді.

Перед учителем початкових класів постають численні завдання: дбати про фізичний розвиток і загартування дітей; формувати в них моральні цінності: доброту, справедливість, гідність, чесність, людяність; привчати їх до посильної праці на благо рідних, близьких, обслуговувати себе; розвивати їх духовно тощо; піклуватися про розвиток органів відчуття і сприймання; турбуватися, щоб кожна дитина оволодівала рідною мовою, елементарними знаннями про довкілля; залучати дітей до участі разом 3 дорослими в народних святах, обрядах для виховання національної свідомості та самосвідомості.

Від того, як педагоги зможуть вплинути на розвиток почуттів дитини, розкрити дітям світ навколишнього життя, розвинути їхню фантазію, залежить виховання майбутніх громадян. Також необхідно враховувати особливості національного характеру й індивідуальні особливості дитини. У цьому сенсі специфіка краєзнавчої роботи з учнями початкових класів пов'язана 3 духовними цінностями як свідомим вибором особистості, що відображає іiі піднесені почуття, позитивне ставлення до життя, людей, довкілля, впливає на мотивацію дій і виконує роль регулятора поведінки та мотивації самостворення.

Розвиток ідеї організації роботи краєзнавчого музею у ВНЗ має певну загальнокультурну, історико-педагогічну традицію, що співвідноситься з основними історичними періодами становлення професійної підготовки майбутніх учителів початкових класів. За результатами теоретичного аналізу зарубіжного та вітчизняного досвіду встановлено, що перехід до систематичної краєзнавчої роботи в системі початкової освіти зумовлений конкретними історичними подіями, закономірностями соціально-політичного, культурного розвитку суспільства, динамікою системи освіти у іiі спрямуванні на виховання почуття патріотизму шляхом використання краєзнавчого потенціалу.

На основі вивчення змісту підготовки майбутніх учителів початкових класів до організації краєзнавчої роботи та роботи краєзнавчого музею при школі у структурі педагогічного факультету вищого педагогічного навчального закладу доведено, що 
вона є ключовим складником, який вимагає від учителя професійно значущих знань, умінь i навичок, спеціальних якостей i здібностей задля успішної організації молодших школярів.

Зважаючи на історичний досвід i сучасні дослідження, основною метою краєзнавчої роботи вчителя початкових класів загальноосвітньої школи необхідно вважати створення та роботу з краєзнавчим музеєм при закладі освіти, оволодіння краєзнавчими знаннями, усвідомлення ними їх духовної значущості. Зміст краєзнавчої діяльності майбутніх педагогів повинен передбачати: оволодіння знаннями про роботу і структуру краєзнавчого музею, краєзнавчими знаннями 3 літературних й інших джерел інформації шляхом безпосереднього вивчення регіону; використання краєзнавчих знань у навчально-виховній роботі; організацію краєзнавчої роботи з учнями в позаурочний час. На сучасному етапі цій проблемі приділяється багато уваги і помітні позитивні зміни прогресиввного характеру.

\section{Література}

1. Грушевський М. С. Ілюстрована історія України / М. С. Грушевський. - К. : Наук. думка, 1992. - 543 с. 2. Коваль Л. В. Професійна підготовка майбутніх учителів початкової школи: технологічна складова : [монографія] / Л. В. Коваль. - Донецьк : Юго-Восток, 2009. - 375 с. 3. Назаренко С. Використання потенціалу музеїв у навчально-виховному процесі / С. Назаренко // Історія України. - 2013. - № 1. - С. 14 16. 4. Стельмахович М. Г. Українська родинна педагогіка / М. Г. Стельмахович. К. : ІСДО, 1996. - 288 с. 5. Ушинський К. Д. Твори в 6-ти томах / К. Д. Ушинський. К. : Рад. шк., 1995. - Т. 6. - С. 562-566. 6. Энциклопедический словарь / под ред. И. Е. Андреевского и проф. Ф. Ф. Петрушевского. - СПб. : Изд-во Ф. А. Брокгауза и И. А. Эфрона, 1901. - Т. 66. - С. 693-694.

УДК 373.5.016:821.161.2.0

Жанна Свірська

\section{ПРОБЛЕМИ ВДОСКОНАЛЕННЯ ЗМІСТУ І СТРУКТУРИ ПРОГРАМ ТА ПІДРУЧНИКІВ ІЗ ЛІТЕРАТУРИ У ВИСВІТЛЕННІ ЄВГЕНА ПАСІЧНИКА}

Свірська Ж. М. Проблеми вдосконалення змісту і структури програм та підручників із літератури у висвітленні Свгена Пасічника.

У статті здійснено спробу висвітлити системний підхід фундатора методики навчання української літератури професора Є. Пасічника в концепцію шкільної гуманітарної освіти. Автор зосереджує увагу на принципах створення змісту, структури підручників та ролі програмових документів як сталих складових літературного розвитку школярів.

Ключові слова: методична система навчання літератури, науково-методична школа, системний підхід, концепція, літературний розвиток, читацька діяльність.

Свирская Ж. Н. Проблемы усовершенствования содержания и структуры программ и учебников по литературе в освещении Евгения Пасичника.

В статье сделано попытку отобразить системный подход Е. Пасичника в концепцию школьного образования. Автор заостряет внимание на принципах содержания, структуры учебников, роли программных документов как составляющих литературного развития школьников.

Ключевые слова: методическая система изучения литературы, научнометодическая школа, системный подход, концепция, литературное развитие, 